\title{
Seasonal patterns of water relationships, photosynthetic pigments and morphology of Actinidia deliciosa plants of the Hayward and Tomuri cultivars
}

\author{
R Savé ${ }^{1 *}$, C Olivella ${ }^{1}, C$ Biel ${ }^{1}, J_{\text {Adillón }}^{2}$, R Rabella ${ }^{3}$ \\ 'Departament de Tecnología Horticola; \\ ${ }^{2}$ Unitat de Suport Técnic, Centre de Cabrils, Institut de Recerca i Tecnologia Agroalimentàries (IRTA), \\ Carretera de Cabrils, s/n E08348 Cabrils, Barcelona; \\ ${ }^{3}$ Servei de Desenvolupament Rural, Diputació de Barcelona, C/Urgell, 187, E08036 Barcelona, Spain
}

(Received 7 July 1993; accepted 4 January 1994)

\begin{abstract}
Summary. - Plant water relationships, photosynthetic pigments, osmotic solutes and several morphological parameters were measured on leaves of 6-yr-old pistillate (Hayward) and 6-yr-old staminate (Tomuri) cultivars of kiwifruit grown under Mediterranean climate conditions, in order to evaluate physiological differences between them, and whether a good discriminatory parameter can be obtained between rooted cuttings. The staminate cultivar had higher leaf turgor and losses turgor at lower leaf-water potential than the pistillate cultivar. This was related to the lower osmotic potential at full turgor in Tomuri compared with Hayward, together with the elastic properties of leaf tissue. Seasonal patterns of water potential components, cuticular water loss, proline, soluble sugars, photosynthetic pigments, cutin, turgid weight/dry weight ratio and specific leaf weight were all similar in both cultivars, whereas the hemicellulose/cellulose ratio differed. Thus, leaf-tissue elasticity is important in determining the drought-resistance strategy of both cultivars, and the chemical composition of the cell walls, which is strongly related to tissue elasticity, could provide a good discriminatory parameter.
\end{abstract}

cell wall composition/leaf water losses/leaf water potential components/volumetric modules of elasticity

Résumé - Valeurs saisonnières des rapports hydriques, des pigments photosynthétiques et de la morphologie d'Actinida deliciosa cultivars Hayward et Tomuri. Les rapports hydriques, les pigments photosynthétiques et quelques paramètres morphologiques ont été mesurés sur des plantes de kiwi de 6 années cv Hayward et Tomuri, cultivées sous des conditions de climat méditerranéen. Le cultivar Tomuri a une turgescence foliaire supérieure et il la perd à des potentiels hydriques plus négatifs que le cultivar Hayward. Ce comportement peut être dû aux basses valeurs du potentiel osmotique et aux caractéristiques d'élasticité des tissus foliaires de ce cultivar. Les valeurs saisonnières des composants du potentiel hydrique, la transpiration cuticulaire, la proline, les sucres solubles, les pigments photosynthétiques, la cutine, les poids spécifique foliaire et poids de turgescence/poids sec sont semblables pour les 2 cultivars. Et seuls sont différents les rapports hémicellulose/cellulose. Par conséquent, les caractéristiques physiologiques et morphologiques des feuilles sont importantes pour définir la stratégie de résistance à la sécheresse des 2 cultivars de kiwi, spécialement l'élasticité des tissus et la composition chimique des parois cellulaires.

composition des parois cellulaires / composants du potentiel hydrique foliaire / module volumétrique d'élasticité / pertes d'eau foliaire

* Correspondence and reprints 


\section{INTRODUCTION}

Although kiwifruit (Actinidia deliciosa Chev) flowers are hermaphroditic, they are physiologically unisexual. For this reason, the presence of staminate and pistillate plants is essential in a kiwifruit orchard to guarantee adequate pollination and fertilization of the female flowers (Biasi and Costa, 1984).

When cultivated under Mediterranean climatic conditions, kiwifruit commonly experiences periods in which plant water deficits develop in response to high atmospheric evaporative demand (Savé et al, 1984; Savé and Adillón, 1990). Strong summer droughts are common in the Mediterranean coastal area of Catalunya, in the northeast of Iberian Peninsula. The potential for growth and/or survival during drought, depends on the capacity and properties of plants for avoidance or tolerance of injury to tissues and desiccation (Morgan, 1984; Turner, 1986).

The aim of the present study, which is included in a larger research project on the ecophysiology of kiwifruit in Catalonia (Savé et al, 1984; Savé and Serrano, 1986; Savé 1988; Savé and Adillón, 1990), was to assess the contribution of osmotic adjustment, tissue elasticity, morphological characteristics and cell-wall composition to drought-resistance mechanisms in both staminate and pistillate kiwifruit cultivars along a crop cycle. This work should lead to a discriminatory parameter between these economically important cultivars, which could allow the determination of the sex of rooted cuttings before establishment in the field.

\section{MATERIALS AND METHODS}

This study was carried out in 1989 in a 6-yr-old orchard of kiwifruit, Actinidia deliciosa cv Hayward (pistillate) and Tomuri (staminate) located in $\mathrm{El}$ Maresme, Catalonia, in the northeast of the Iberian Peninsula $\left(41^{\circ} 25^{\prime} \mathrm{N}, 2^{\circ} 23^{\prime} \mathrm{E}\right)$. The climate is classified as Mediterranean (hot, dry summers and cold, wet winters). The kiwifruits were planted at a density of 333 plants $\mathrm{ha}^{-1}$, and were supported with a T-trellis with the cross-beam approximately $1.8 \mathrm{~m}$ above the ground.

Irrigation provided $150-60-200 \mathrm{~kg} \mathrm{ha}^{-1}$ of $(\mathrm{N}$ : $\mathrm{P}_{2} \mathrm{O}_{5}: \mathrm{K}_{2} \mathrm{O}$ ) and was applied when the soil matric potential reached $-0.015 \mathrm{MPa}$. In winter $2-2.5 \mathrm{~kg}$ $\mathrm{m}^{-2}$ of manure was applied.

The soil matric potential was determined with Soilmoisture 2725 tensiometers (Soilmoisture, Santa Barbara, $\mathrm{Ca}$ ) located at a depth of 10 and $40 \mathrm{~cm}$ and at $20 \mathrm{~cm}$ from the emitter.

A pressure-volume $(P-V)$ technique described by Tyree and Richter $(1981,1982)$ was used to compare the tissue water relationship of Hayward and Tomuri cultivars during spring (May 5, 1989), summer (July 13, 1989) and autumn (October 2, 1989). Several fully developed south-facing leaves were randomly selected from roughly the middle canopy height in the early morning (Savé et al, 1993).

The leaves used for the P-V curve analysis were analyzed for determination of the saturated weight/dry weight ratio (TW/DW) and specific leaf weight (SLW). The values obtained by difference between distinct fresh weights in the time interval below the point of zero turgor were considered as cuticular water losses (Araus et al, 1991).

Chlorophyll $a, b$ and total were determined by extraction with dimethylformamide and read in a UV-VIS spectrophotometer, Shimadzu 260, according to Inskeep and Bloom (1985). Carotenoids were extracted simultaneously with the chlorophyll and determined using the equations proposed by Lightenthaler and Wellburn (1983) for the determination of carotenoids in a $80 \%$ acetone/water extracting solution.

Proline was determined according to a modification of the method of Bates (1973) with a Shimatzu 260 spectrophotometer at $560 \mathrm{~nm}$. Soluble sugars were determined in dry samples according to Wristler and Wolform (1962).

At the summer sampling, the leaves of pistillate and staminate kiwifruit cultivars were harvested in order to analyze their cellulose, hemicellulose, lignin and cutin compositon (Gœring and Van Sœst, 1970)

Values were compared by one-way ANOVA test. All means were compared at the 0.05 level of significance.

\section{RESULTS AND DISCUSSION}

The osmotic potentials at full and zero turgor were always lower and the values of the volumetric modulus of elasticity were always higher in Tomuri than in Hayward cultivar (table I).

The decrease in osmotic potentials at full and zero turgor suggests some degree of osmotic adjustment by net accumulation of so- 
Table I. Seasonal patterns of osmotic potential at full $\left(\psi_{\pi 100}\right)$ and zero turgor $\left(\psi_{\pi 0}\right)$, volumetric modulus of elasticity $\left(\varepsilon_{100}\right)$, cuticular water loss, specific leaf weight (SLW) and turgid weight to dry weight ratio (TW/DW) of leaves of Hayvard and Tomuri kiwifruit cultivars.

\begin{tabular}{|c|c|c|c|c|c|c|}
\hline \multirow[t]{2}{*}{ Parameter } & \multicolumn{3}{|c|}{ Hayward } & \multicolumn{3}{|c|}{ Tomuri } \\
\hline & May 9 & July 13 & October 2 & May 9 & July 13 & October 2 \\
\hline$\psi_{\pi_{100}}(\mathrm{MPa})$ & $-0.78 \pm 0.08^{a^{*}}$ & $-1.34 \pm 0.11^{b}$ & $-1.53 \pm 0.35^{b}$ & $-1.25 \pm 0.24^{\mathrm{a}^{*}}$ & $-1.73 \pm 0.41^{b}$ & $-1.74 \pm 0.13^{b}$ \\
\hline$\psi_{\pi_{0}}(\mathrm{MPa})$ & $-1.39 \pm 0.11^{a^{*}}$ & $-2.25 \pm 0.15^{b}$ & $-1.95 \pm 0.39^{b^{*}}$ & $-2.06 \pm 0.16^{\mathrm{a}^{*}}$ & $-2.33 \pm 0.31^{a}$ & $-2.37 \pm 0.23^{\mathrm{a}^{*}}$ \\
\hline$\varepsilon_{100}(\mathrm{MPa})$ & $5.73 \pm 0.22^{\mathrm{a}^{*}}$ & $5.90 \pm 0.90^{\mathrm{a}^{*}}$ & $8.04 \pm 1.79^{\mathrm{a}^{*}}$ & $7.17 \pm 1.12^{\mathrm{a}^{*}}$ & $9.31 \pm 2.02^{\mathrm{a}^{*}}$ & $10.13 \pm 1.87^{\mathrm{a}}$ \\
\hline $\begin{array}{l}\text { Cuticular water } \\
\text { loss }\end{array}$ & & & & & & \\
\hline $\begin{array}{l}\left(\mathrm{mg} \cdot \mathrm{g}^{-1}\right. \\
\left.\mathrm{DW} \cdot \min ^{-1}\right)\end{array}$ & $6.23 \pm 1.19^{a}$ & $5.45 \pm 1.00^{\mathrm{ab}}$ & $4.44 \pm 0.29^{b}$ & $6.93 \pm 0.73^{a}$ & $4.33 \pm 0.18^{b}$ & $3.57 \pm 0.27^{c}$ \\
\hline $\operatorname{SLW}\left(\mathrm{mg} \cdot \mathrm{cm}^{-2}\right)$ & $7.15 \pm 0.08^{a}$ & $10.70 \pm 2.40^{b}$ & $16.47 \pm 0.37^{c^{*}}$ & $6.54 \pm 0.73^{a}$ & $9.69 \pm 0.60^{b}$ & $14.80 \pm 0.42^{c^{*}}$ \\
\hline TW/DW & $5.45 \pm 0.44^{\mathrm{a}}$ & $4.53 \pm 0.19^{b}$ & $3.74 \pm 0.30^{c}$ & $6.15 \pm 0.24^{\mathrm{a}}$ & $4.36 \pm 0.25^{b}$ & $3.44 \pm 0.10^{c}$ \\
\hline
\end{tabular}

Each value is the mean of 4 observations \pm standard deviation. Distinct letters indicate significant differences between seasonal samples. The presence of asterisk indicates significant differences between cultivars.

lutes in response to water deficits promoted by the evaporative demand of the atmosphere as shown in figure 1 (Morgan, 1984; Turner, 1986). This decrease could be partly caused by the concentration of solutes (Ackerson and Hebert, 1981; Sobrado, 1986), which can be deduced from the reduction of the TW/DW ratio and the increase in SLW throughout the season, which probably provided thicker walls and reduced cell volume (Jensen and Henson, 1990). The reduction in TW/DW observed throughout the season could be due to accumulation of fibrous constituents in the leaves, particularly hemicellulose. These cell-wall components have important properties such as ion-binding capacity and water-holding capacity (Rascio et al, 1990).

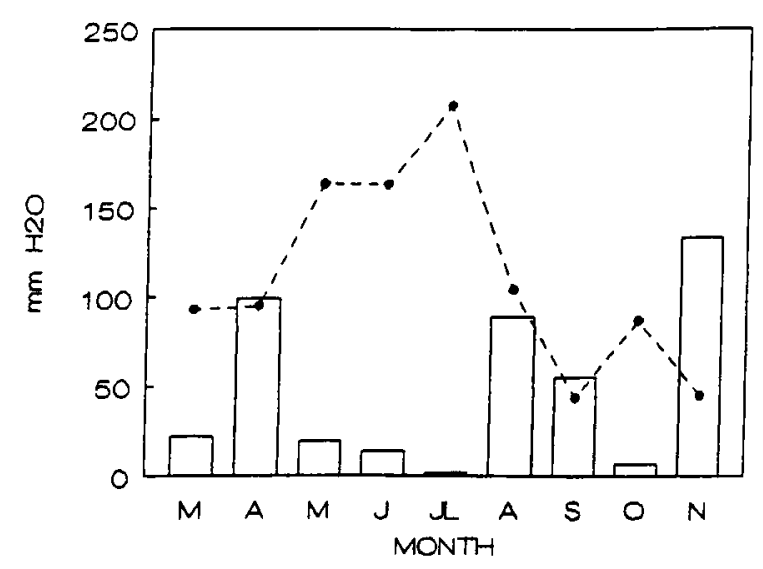

Fig 1. Monthly evaporation (--0--) and rainfall $(\square)$ values from March to November 1989.
Proline showed higher values in the spring samples than in the summer and autumn samples, which had similar values (table II). This may be caused by a large seasonal variation in the concentration of macronutrients and micronutrients in the leaves of kiwifruit (Smith et al, 1985).

The soluble sugar values did not show differences between cultivars, but showed a significant decrease in the summer values, which could be attributed to increased translocation for plant growth (Munns, 1988) (table II).

The higher values of the volumetric elastic modulus observed in the staminate compared with the pistillate cultivars seem to indicate a lower tissue elasticity, which provides a smaller contribution to osmotic adjustment (Myers and Neales, 1986; Robichaux et al, 1986). According to Robichaux et al (1986), although the basic mechanism of the variation in tissue elastic properties is unknown, some evidence suggests that several factors may be involved, eg, cell size, age of leaf tissue, cell-wall composition and apoplasmic water loss.

Thus, the cultivars studied had the same age, had no significant differences in TW/DW ratio and SLW, which may provide an indirect measure of cell size (Jensen and Henson, 1990), and apoplasmic water loss might only affect the calculated value of elastic modulus (Robichaux et al, 1986). For this reason, detected differences in tissue elasticity can be attributed to cell-wall composition. There were thus significant differences in the hemicellulose/cellulose ratio of leaves between 
Table II. Seasonal patterns of chlorophyll a (Chla), chlorophyll b (Chlb), total chlorophyll (Chltotal) and the ratio Chla/Chlb, carotenoids, soluble sugars, proline, cutin and hemicellulose/cellulose ratio in leaves of Hayward and Tomuri kiwifruit.

\begin{tabular}{|c|c|c|c|c|c|c|}
\hline \multirow[t]{2}{*}{ Parameter } & \multicolumn{3}{|c|}{ Hayward } & \multicolumn{3}{|c|}{ Tomuri } \\
\hline & May 9 & July 13 & October 2 & May 9 & July 13 & October 2 \\
\hline Chla & $222.4 \pm 38.1^{\mathrm{a}}$ & $193.2 \pm 27.6^{\mathrm{a}}$ & $148.8 \pm 9.1^{b}$ & $252.5 \pm 41.0^{\mathrm{a}}$ & $154.6 \pm 18.8^{b}$ & $143.3 \pm 7.5^{b}$ \\
\hline Chlb & $55.7 \pm 7.5^{\mathrm{a}}$ & $53.4 \pm 7.0^{\mathrm{a}}$ & $50.1 \pm 3.9^{a}$ & $53.8 \pm 9.3^{\mathrm{a}}$ & $42.8 \pm 6.1^{\mathrm{a}}$ & $42.3 \pm 2.2^{\mathrm{a}}$ \\
\hline Chlt & $278.1 \pm 45.3^{a}$ & $246.6 \pm 34.5^{\mathrm{a}}$ & $198.9 \pm 12.7^{\mathrm{a}}$ & $306.3 \pm 50.3^{a}$ & $197.4 \pm 24.7^{b}$ & $185.6 \pm 9.4^{b}$ \\
\hline $\begin{array}{l}\text { Chla/Chlb } \\
\text { Carotenoids }\end{array}$ & 4.0 & 3.6 & 3.0 & 4.7 & 3.6 & 3.4 \\
\hline $\begin{array}{l}\text { Larotenolas } \\
\left(\mathrm{mg} \cdot 100 \mathrm{~g}^{-1} \mathrm{FW}\right)\end{array}$ & $52.4 \pm 4.0^{\mathrm{a}}$ & $41.2 \pm 5.2^{\mathrm{a}^{\star}}$ & $26.9 \pm 1.6^{b}$ & $60.1 \pm 3.4^{a}$ & $30.1 \pm 2.2^{b^{*}}$ & $26.9 \pm 1.4^{b}$ \\
\hline $\begin{array}{l}\text { Soluble sugars (\%) } \\
\text { Proline }\left(\mu \mathrm{g} \cdot \mathrm{g}^{-1} \mathrm{FW}\right)\end{array}$ & $8.4 \pm 0.4^{a}$ & $3.9 \pm 0.6^{\mathrm{c}}$ & $6.7 \pm 0.1^{b}$ & $8.2 \pm 0.6^{\mathrm{a}}$ & $4.0 \pm 0.3^{b}$ & $8.3 \pm 0.4^{\mathrm{a}}$ \\
\hline $\begin{array}{l}\text { Cutin (\% DW) } \\
\text { Hemicellulose/ } \\
\text { cellulose }\end{array}$ & $129.3 \pm 22.0^{\mathrm{a}}$ & $\begin{array}{r}15.9 \pm 0.9^{\mathrm{b}} \\
1.9 \pm 0.7^{\mathrm{a}} \\
0.95 \pm 0.2^{\star}\end{array}$ & $13.4 \pm 2.1^{b}$ & $106.3 \pm 7.5^{\mathrm{a}}$ & $\begin{aligned} 22.0 & \pm 1.4^{b} \\
4.0 & \pm 1.6 \\
0.74 & \pm 0.19^{\star}\end{aligned}$ & $16.2 \pm 0.5^{b}$ \\
\hline
\end{tabular}

Each value is the mean of 8 values \pm standard deviation. Distinct letters indicate significant differences between seasonal samples. The presence of asterisk indicates significant differences between cultivars.

cultivars. Thus, values of the ratio were significantly higher in Hayward than in Tomuri cultivars (table II), which is in agreement with Robichaux et al (1986) who stated that an increase in the ratio of pectin (in our case included in the same fraction as hemicellulose) to cellulose in the cell wall could result in an increase in wall elasticity.

On the other hand, results shown a nonsignificant tendency to a decrease in tissue elasticity with age, which can be related to the higher plasticity of young growing cells and tissues (Zimmermann, 1978).

Cuticular water loss rates and cutin (tables I and II) do not show significant differences between kiwifruit cultivars throughout the study, but a significant decrease was observed throughout the season. This can be attributed to leaf ontogenic changes (Solárová and Pospísilova, 1983; Torrecillas et al, 1988), together with hardening in response to environmental drought stress (Martin et al, 1987).

Photosynthetic pigments, chlorophylls and carotenoids showed no significant differences between the cultivars, and have similar seasonal patterns. The pigments had higher values during the spring with a slight decrease throughout the season, which can be associated with phenomena of leaf development and senescence (Solárová and Pospísilova, 1983).
From our results we concluded that the Hayward cultivar had a mechanism of drought tolerance based on high tissue elasticity (Levitt, 1980; Morgan, 1984). Tissue elasticity is important in determining how much of a change in turgor potential will occur for a given change in relative water content (Roberts et al, 1981; Robichaux et al, 1986). The high elasticity of tissues permits a greater utilization of assimilates and nutrients for growth (Munns, 1988) and turgor-mediated processes, such as elongative growth or photosynthesis (Bradford and Hsiao, 1982), are less affected than under lower elasticities.

The Tomuri cultivar presented a different mechanism of drought tolerance. This was based on an active accumulation of solutes, osmotic adjustment (Levitt, 1980; Morgan, 1984), together with less elastic tissues, and allows more negative water potentials to be reached for a given change in water volume, facilitating continued water uptake for drying soils. Low tissue elasticity may be an important characteristic which permits the attainment of low water potentials without the development of detrimental water deficits (Bowman and Roberts, 1985).

Furthermore, from our results, we have deduced that tissue elasticity is a good discriminatory parameter of studied cultivars, and, consequently, the simple analysis of the hemicellulose/cellulose ratio could provide an interesting discriminatory test between these economically important cultivars. 


\section{ACKNOWLEDGMENTS}

We thank $L$ Serrano and O Marfá for their help in preparing this manuscript. This study received financial support from INIA (No 7960) and CIRIT.

\section{REFERENCES}

Ackerson RC, Hebert R (1981) Osmoregulation in cotton in response to water stress. I. Alterations in photosynthesis, leaf conductance, translocation and ultrastructure. Plant Physiol 67, 484-488

Araus JL, Febrero A, Vendrell P (1991) Epidermal conductance in different parts of durum wheat grown under Mediterranean conditions: the role of epicuticular waxes and stomata. Plant Cell Environ 14, 545-558

Bates LS (1973) Rapid determination of free proline for water-stress studies. Plant Soil 39, 205-297

Biasi R, Costa G (1984) Aspetti e problemi dell'impollinazione dell'Actinidia. Frutticoltura 9-10, 45-50

Bowman WD, Roberts SW (1985) Seasonal changes in tissue elasticity in chaparral shrubs. Physiol Plant 65, 233-236

Bradford KJ, Hsiao TC (1992) Physiological response to moderate water stress. In: Physiological Plant Ecology II. Vol 12B (OL Lange, PS Nobel, CB Osmond, $\mathrm{H}$ Ziegler, eds) Springer Verlag, Berlin, 263-324

Gœring HK, Van Soest EJ (1970) Forage fiber analysis. Agricultural Handbook 379. Edit Agric Res Service USDA

Inskeep W, Bloom P (1985) Extinction coefficients of chlorophyll $\mathrm{a}$ and $\mathrm{B}$ in dimetiflormarmide and $80 \%$ acetone. Plant Physiol 77, 483-485

Jensen CR, Henson IE (1990) Leaf water relations characteristics of Lupinus augustifolius and $L$ consentinii. Oecologia (Berl) 82, 114-121

Lightenthaller HK, Wellburn AR (1983) Determinations of total carotenoids and chlorophylls a and $b$ of leaf extracts in different solvents. Biochem Soc Trans 630, 591-592

Levitt J (1980) Responses of plants to environmental stresses. II: Water, radiation, salt and other stresses. Physiological Ecology Series. Acad Press, New York, 25-211

Martin U, Pallardy SG, Behari ZA (1987) Dehydration tolerance of leaf tissues of leaf tissues of sex woody angiosperm species. Physiol Plant 69, 182-186
Morgan JM (1984) Osmoregulation and water stress in higher plants. Annu Rev Plant Physiol 35, 299-319

Munns $R$ (1988) Why measure osmotic adjustment? Aust J Plant Physiol 15, 717-726

Myers BA, Neales TF (1986) Osmotic adjustment induced by drought in seedlings of Eucalipthus species. Aust J Plant Physiol 13, 597-603

Rasio A, Cedola MC, Toponi M, Flagella Z, Wittmer G (1990) Leaf morphology and water status changes in Triticum durum under water stress. Physiol Plant 78, 462-467

Roberts SW, Strain BR, Knoerr KR (1981) Sesaonal variation of leaf tissue elasticity in four forest tree species. Physiol Plant 52, 245-250

Robichaux RH, Holsinger KE, Morse SR (1986) Turgor maintenance in Hawaiian Dubautia species: the role of variation in tissue osmotic and elastic properties. In: On the economy of plant form and function (TJ Givnish, ed) Cambridge, Cambridge Univ Press, 253-380

Savé R (1988) Osmotic adjustment of vitreo plants and rooted cuttings of kiwifruits. Proc 6th Congress of FESPP Split, Yugoslavia

Savé R, Adillón J (1990) Comparison between plant water relations of in vitro plants and rooted cuttings of kiwifruit. Acta Hortic 282, 193-197

Savé R, Adillón J, Marfá O (1984) Stomatal conductance behaviour of Actinidia chinensis Planch var Hayward during summer. Proc 4 th Congress of FESPP, Strasbourg, France

Savé R, Serrano L (1986) Some physiological and growth responses of kiwifruit (Actinidia chinensis) to flooding. Physiol Plant 66, 75-78

Savé R, Peñuelas J, Marfà O, Serrano L (1993) Changes in leaf osmotic and elastic properties and canopy structure of strawberry under mild water stress. Hortscience 28(9), 925-927

Smith GS, Asher CJ, Clark CJ (1985) Kiwifruit Nutrition. Diagnosis of Nutritional Disorders. AGPRESS Communications LTD. Wellington, New Zealand

Sobrado MA (1986) Aspects of tissue water relations and seasonal changes of leaf water potential components of evergreen and deciduous species coexisting in tropical dry forest. Oecologia (Berl) 68, 413-416

Solárová J, Pospísilova J (1983) Photosynthetic characteristics during ontogenesis of leaves. 8. Stomatal diffusive conductance and stomata reactivity. Photosynthetica 17, 101-151

Torrecillas A, Ruiz-Sánchez MC, Del Amor F, León A (1988) Seasonal variation on water relations of Amygdalus communis $\mathrm{L}$ under drip irrigated conditions. Plant Soil 196, 215-220 
Turner NC (1986) Adaptation to water deficits: a changing perspective. Aust J Plant Physiol 13, 175-190

Tyree MT, Richter H (1981) Alternative methods of analyzing water potential isotherms: some cautions and clarifications. I. The impact of non-ideality and some experimental errors. $J$ Exp Bot 32, 643-653

Tyree MT, Richter H (1982) Alternative methods of analyzing water potential isotherms: some cautions and clarifications. II. Curvilinearity in water potential isotherms. Can J Bot 60, 911916

Wristler R, Wolform L (1962) A Carbohydrate Chemistry. Vol 1. Analysis and Preparation of Sugars. Acad Press, New York

Zimmermann U (1978) Physics of turgor and osmoregulation. Annu Rev Plant Physiol 29, 121-148 